\title{
TorsionAnalyzer: exploring conformational space
}

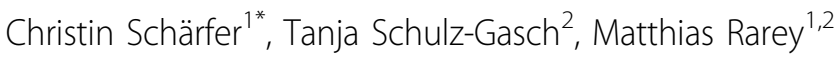 \\ From 8th German Conference on Chemoinformatics: 26 CIC-Workshop \\ Goslar, Germany. 11-13 November 2012
}

Molecular conformations are used in a wide range of virtual screening applications to represent the conformational flexibility of a molecule. As the underlying conformational model has a major influence on the results of these applications, a closer insight into the conformational space of molecules is very important.

We developed a new interactive graphical software tool for conformation analysis called TorsionAnalyzer. The tool uses a predefined set of over 450 SMARTS patterns to analyze the torsion angles of an input conformation. Each pattern describes a torsion angle and is associated with frequency histograms derived from CSD [1] and PDB [2] data. For each pattern a list of allowed torsion angles was automatically derived from the torsion histograms. Rotatable bonds of a conformation are colored according to their classification into usual, borderline and unusual torsion angles, using the list of allowed angles from the corresponding patterns. This allows the user to see at a glance if one of the torsion angles of an examined conformation is out of the ordinary. The TorsionAnalyzer supports easy modification of the existing SMARTS patterns as well as the preparation and storage of different sets of patterns for different sets of molecules.

\footnotetext{
Author details

${ }^{1}$ Center for Bioinformatics (ZBH), Bundesstr. 43, 20146 Hamburg, Germany.

${ }^{2}$ F. Hoffmann-La Roche Ltd., 4070 Basel, Switzerland.
}

Published: 22 March 2013

\section{References}

1. Allen FH: The Cambridge Structural Database: a quarter of a million crystal structures and rising. Acta Cryst 2002, B58:380-388.

2. Berman HM, et al: The Protein Data Bank. Nucleic Acids Res 2000, 28:235-242.

doi:10.1186/1758-2946-5-S1-P3

Cite this article as: Schärfer et al:: TorsionAnalyzer: exploring conformational space. Journal of Cheminformatics 2013 5(Suppl 1):P3.

* Correspondence: schaerfer@zbh.uni-hamburg.de

${ }^{1}$ Center for Bioinformatics (ZBH), Bundesstr. 43, 20146 Hamburg, Germany Full list of author information is available at the end of the article
Publish with ChemistryCentral and every scientist can read your work free of charge

"Open access provides opportunities to our colleagues in other parts of the globe, by allowing anyone to view the content free of charge."

W. Jeffery Hurst, The Hershey Company.

- available free of charge to the entire scientific community

- peer reviewed and published immediately upon acceptance

- cited in PubMed and archived on PubMed Central

- yours - you keep the copyright

Submit your manuscript here:

http://www.chemistrycentral.com/manuscript/

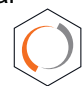

Chemistry Central 